\title{
The Effect of Lactation Number on Physico-Chemical and Microbiological Parameters of Milk from Small and Medium Bovine Farms located in Transilvania Region
}

\author{
Ioan $\mathrm{HAN}^{1}$, Otilia BOBIŞ², Liviu Alexandru MĂRGHITAȘ ${ }^{1}$ \\ ${ }^{1}$ Faculty of Animal Science and Biotechnologies, University of Agricultural Sciences and Veterinary \\ Medicine - 400372, Cluj-Napoca, Mănăștur, 3-5, România \\ ${ }^{2}$ Life Science Institute "King Michael I of Romania", University of Agricultural Sciences and Veterinary \\ Medicine - 400372, Cluj-Napoca, Mănăștur, 3-5, România \\ *corresponding author: obobis@usamvcluj.ro
}

Bulletin UASVM Animal Science and Biotechnologies 77(2)/2020

ISSN-L 1843-5262; Print ISSN 1843-5262; Electronic ISSN 1843-536X

DOI:10.15835/buasvmcn-asb: 2020.0007

\begin{abstract}
Milk is a biological fluid where fats are distributed in microglobules $\left(2-10 \mathrm{million} / \mathrm{cm}^{3}\right)$, in an aqueous solution of proteins, carbohydrates and other substances. The main physico-chemical properties of milk are: density, viscosity, specific heat, boiling point, freezing point, $\mathrm{pH}$ and total acidity. Microbiological quality is represented by the presence or absence of pathogens or alterations, which can contaminate milk as a raw material. The comparative nutritional and microbiological quality of milk from three counties, from Transilvania Region, were fat percentage, total protein, casein content, lactose, $\mathrm{pH}$, urea, total germ count (TGC) and somatic cell count (SCC). The best percentages of fat were obtained in Bihor County, with mean values of all lactations of $4.00 \%$. This was followed by Hunedoara County with 3.97\% and Alba County with 3.95\%. The highest protein percentages were obtained in samples collected in Bihor County, with mean values of $3.57 \%$, followed by Hunedoara County with 3.52\% and Alba County with 3.51\%. Most physicochemical indices fall within the normal limits, unanimously accepted by existing standards, but microbiological indices in some cases do not meet the requirements for the admission of raw milk.
\end{abstract}

Keywords: analysis, farms, microbiology, milk.

\section{Introduction}

According to Codex Standard 206-1999, "Milk is the normal mammary secretion of milking animals obtained from one or more milkings without either addition to it or extraction from it, intended for consumption as liquid milk or for further processing". Generally, milk is defined by its chemical constituents, such as fat and protein contents directly resulting from feeding practices (Demeyer \& Doreau, 1999), type of cow breed and also lactation stage (Kelsey et al., 2003; Vijayakumar et al., 2017). Because raw milk is used for consumption, or may be processed or used as ingredient in different food products, it has to follow strict standards of composition and hygiene. The hygienic profile is characterized by the contamination level and specific distribution of different microorganisms. This is strictly correlated to animal age, udder health (Kilic \& Kilic, 1994; Othmane et al., 2002; Matei et al., 2010; Țibulcă et al., 2012) animal age and milking conditions (Bony et al., 2005; Salovuo et al., 2005; Van Nieuwenhove et al., 2009; Falchero et al., 2010) and hygienic conditions in the stable 
(Mironeasa et al., 2011; Onaciu et al., 2015; El Mahdy et al., 2016). The milk composition also varies with other factors, such as environmental temperature (Yetismeyen, 2000, Ozrenk \& Selcuk, 2008), seasonal variations (Bruhn \& Franke, 1997), the light-to-dark ratio (Tucker, 1989; Casati et al., 1998). The influence of climatic factors on milk components can be correlated to some parameters such as region of production (Karoui et al., 2005), season (Formaggioni et al., 2002; Alomirah et al., 2007; Van Nieuwenhove et al., 2009) and year of production.

Chemical composition of milk depends also on animal species (Table 1). Milk fat presents the largest quantitative variation among all components of milk (the amount of fat lies between $2.8-4 \%)$. It is dependent on race, individual, age, stage of lactation, feed, season, health, etc. Simple dairy lipids are represented by mixture of glycerides and steroids, in the proportion of $0.01-0.17 \%$. Complex lipids are represented by phosphatides or phospholipids. Along with the actual fat, some liposoluble compounds such as sterin (cholesterol and lanosterol), pigments (carotenoids), liposoluble vitamins $\left(\mathrm{A}, \mathrm{D}_{2}, \mathrm{E}, \mathrm{K}\right)$, free fatty acids, are present also in milk (Iurca \& Răducu, 2005; Mehta, 2015).

Milk protein content varies depending on: species, race, diet, lactation stage and physiological status of the animal. In milk, there are three main groups of proteins: casein, whey proteins and proteoso-peptones. Casein is found in the form of mycelium $(20 \%$ organic calcium linked to mycelium, 80\% mineral calcium) and represents $80 \%$ of milk proteins; the remaining $20 \%$ is whey protein. More than 20 constituents of casein have been identified, among them casein $\mathrm{K}$ presents the most important role for the cheese industry (Iurca \& Răducu, 2005; Mehta, 2015).

In milk, casein is combined with calcium phosphate, giving calcium phosphosaccinate, soluble in water, which precipitates in an acidic medium $(\mathrm{pH}$ $=4.6$ ) or enzymatically, resulting in the coagulum. Serum proteins represent $18-21 \%$ of total milk protein. They are lactalbumin, lactoglobulin (s), serum albumin, immunoglobulins, proteases and peptones. Non-protein nitrogenous substances represent $5 \%$ of the total nitrogen of the milk are made up of: urea, uric acid, ammonia, creatine, creatinine, etc. (Usturoi, 2007).

Lactose is the characteristic sugar of milk, which gives its sweet taste. Under the action of intestinal lactase, lactose decomposes into glucose and galactose. The lactose content of milk varies between $2.84-7.66 \%$. In milk, lactose is found as two isomers: $\alpha$ and $\beta$ and are in equilibrium.

Freezing point (crioscopic point) varies between $-0.540^{\circ} \mathrm{C}$ and $-0.570^{\circ} \mathrm{C}$ and is determined by the concentration of all dissolved substances (lactose, minerals and nitrogen) (Banu et al. 2009). Total proteins and lipids do not influence the cryoscopic point (Usturoi, 2007).

Mineral substances in milk are present in an average of $0.75 \%$. The main components of milk minerals are calcium phosphate and potassium chloride. Macroelements are represented by $\mathrm{Ca}$, $\mathrm{P}, \mathrm{K}, \mathrm{Na}, \mathrm{Cl}, \mathrm{Mg}$ and $\mathrm{S}$. Calcium and phosphorus are linked to $20 \%$ casein in the form of a calcium phospho-caseinate complex. Magnesium is also related to casein in a proportion of $33 \%$ of the tainted amount in milk. The most important microelements identified in milk are $\mathrm{Fe}, \mathrm{Cu}, \mathrm{Mo}, \mathrm{Li}$, $\mathrm{Sr}, \mathrm{Cr}, \mathrm{Co}$ and others, with an important role in the normal development of vital organisms (Răducu, 2014). Chemical composition of milk also presents

Table 1. Chemical composition of milk from the main animal species (Usturoi, 2005)

\begin{tabular}{lccccc}
\hline \multirow{2}{*}{ Specification } & \multirow{2}{*}{ Unit } & \multicolumn{4}{c}{ Animal species } \\
\cline { 3 - 6 } & & Cow & Buffalo & Goat & Sheep \\
\hline Energie & Kcal/l & $650-720$ & $755-1425$ & $600-700$ & $1050-1150$ \\
\hline Dry weight & $\%$ & $12.6-12.8$ & $16.6-17.5$ & $11.3-13.4$ & $17.5-18.3$ \\
\hline Fat & $\%$ & $3.7-6.3$ & $6.8-7.9$ & $3.3-4.1$ & $6.6-7.1$ \\
\hline Proteins & $\%$ & $3.3-4.2$ & $4.0-4.1$ & $2.9-3.3$ & $5.2-5.7$ \\
\hline Lactose & $\%$ & $4.7-4.8$ & $4.8-5.0$ & $4.4-4.8$ & $4.6-4.9$ \\
\hline Minerals & $\%$ & $0.7-0.9$ & $0.7-0.8$ & $0.7-0.8$ & $0.8-0.9$ \\
\hline
\end{tabular}


small amounts of vitamins, enzymes, pigments, gases and other components.

Hygienic quality of milk is represented by the presence or absence of pathogens or alterations that can contaminate milk as a raw material. Obviously, the presence of pathogens in milk can have serious consequences for the consumer and exclude milk from consumption.

Pathogenic germs in milk are Salmonella, Escherichia coli, Staphylococcus aureus, Yersinia enterocolitica, Listeria monocytogenes etc. Their origin is different, some come from the dairy animal (ex-inflammation of the mammary gland - Staphylococcus), and others come from the surface of the milking equipments, from the air of the milking rooms, from the milking staff. However, the second category of alternatives that may cause changes (color, consistency, smell and taste, presented earlier), and may determine the product unsuitable for consumption, should not be neglected.

Immediately after production, the number of microorganisms in milk remains constant or even decreases due to the existence of mechanisms that protect the mammary gland against aggression of microorganisms. This period may be extended from 2 to 10 hours if the milk is cooled immediately after milking at temperatures below $8^{\circ} \mathrm{C}$ (Sala, 2008).

Another indicator of the hygienic quality of milk is the number of somatic cells in milk that gives us indications, mainly, of the health of the mammary gland. There are three types of cells in the milk: epithelial cells, macrophages and polymorpho-nuclear leukocytes.

Milk from the healthy mammary gland contains mainly epithelial and macrophage cells; therefore, the milk contains a certain number of somatic cells, even if it comes from the healthy mammary gland. In the case of mammary gland disorders, the number of somatic cells in milk increases mainly by increasing the number of polymorpho-nuclear cells.

The total somatic cell count in milk ranges from 50,000 to 100,000 cells $/ \mathrm{ml}$ for healthy udder milk and may reach 5-7 million cells $/ \mathrm{ml}$ in colostrum or even 5-10 million in milk from cows with mammary gland infections. The completely raw milk from the healthy and milking cage, under proper hygiene conditions, contains a small number of cells, ranging from 200,000 to 300,000 cells $/ \mathrm{cm}^{3}$ of milk (Sala, 2008).

Even in the period of normal secretion, the number of cells is different. Thus, it increases towards the end of milking, evening versus morning, summer versus winter and during several lactations. There are also individual variations in cell numbers and race-dependent variations.

The aim of this study is to determine and compare the chemical and microbiological characteristics of milk collected from bovine farms in three different counties (Apuseni Mountains area) in Romaia, located in different geographic regions, and describe the connections between lactation number and physico-chemical characteristics of milk.

\section{Material and Methods}

Biological material. For the phenotypic characteristics of the cows from Bălţata Românească breed from Apuseni Mountains, research was made in 16 representative exploitations from 3 counties (Alba, Bihor, Hunedoara) from this area on a total of 214 lactation cows as follows:

- Alba County $\left(46^{\circ} 08^{\prime} 00^{\prime \prime} \mathrm{N} 23^{\circ} 32^{\prime} 00^{\prime \prime} \mathrm{E}\right)$ - 7 farms with 80 cows

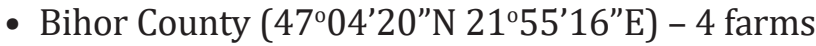
with 69 cows

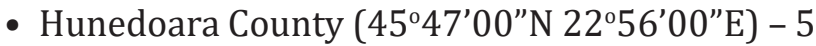
farms with 65 cows.

Work methods. For qualitative and quantitative and determination of milk production in investigated cows, we carried out periodic controls of milk production during 2015 and 2017.

Official control of milk production performance was carried out in compliance with the control methodology regulated by the national legislation (OM 18/2006, 19/2006, with subsequent amendments and completions), legislation approved by the competent international body, namely the International Committee for Animal Performance Control (ICAR).

The control method used was AT 6 (the interval between controls was 42 days).

The research for the present work use the ANARZ technique, based on a control chart weighing and paralleling milk samples from each control and from each cow. The milk analysis has been made in SC Albalact SA milk laboratory following standard analytical methods and Romanian standards: Council Directive 91/180/ 
EEC, fat content (SR EN ISO 1211:2010), somatic cell number (SR EN ISO 13366-3:2001) and solids non-fat content (SR ISO 6731:1996).

\section{Results and Discussions}

All animal exploitations from the three counties present different results in the chemical composition and also in the microbiological parameters of milk. Differences were observed also between lactation number and quality of milk. Samples from Hunedoara County were the most homogenous during all lactation periods. Fat content for the milk from Hunedoara County lies between $3.88-4.03 \%$. The highest fat content was registered in $4^{\text {th }}$ lactation $(4.03 \%)$. The highest quantity of proteins was registered in the $5^{\text {th }}$ lactation, and consequently the highest amount of casein and lactose. Non-fat dry weight of milk samples from all lactations was $9.42 \%$.

Fat content determined in samples from Alba County, have values between 3.86 and $4.01 \%$, with a mean of $3.95 \%$. Fat content increases with lactation number, first lactation having the lowest value of fat and 5th lactation the highest value. Regarding protein content, values between 3.44 and $3.54 \%$ were registered, with higher values again in the 5 th lactation. Casein from milk samples collected in Alba County, were similar to the samples from Hunedoara County, but lactose had higher values compared to the latter ones (mean of $4.77 \%$ and $4.73 \%$ respectively) (Table 2). Samples collected from Bihor County presented the highest content of fat (mean of $4.00 \%$ ), protein $(3.57 \%)$ and casein $(2.81 \%)$, compared to the other samples from the present study. Comparing with other literature studies, from Romania (other geographical origins) (Cziszter et al., 2008; Gâlcă et al., 2008) and abroad (Fahmid et al., 2016; Rafiq et al., 2016), by far, the samples from Bihor County have the highest nutritional values due to lipid, protein and sugar content.

Similar values for these parameters were obtained by Onaciu et al. (2015) from milk collected in Sălaj County from Red Holstein cows. Other studies (Răducu et al. 2012; Jurco et al., 2016; Onaciu et al., 2016) obtained also similar values for the chemical parameters of milk from Friesian - Black Spotted Breed or Bălțata Românească Breed. Vegetation and geographical landscape have an important role in the chemical composition of milk, more important than the race of the animal.

The $\mathrm{pH}$ of milk is slightly acidic (6.5-6.7). Milk contains different weak organic acids (lactic acid, butyric acid, propionic acid, acetic and citric acid), contributing to its flavor and aroma of milk and milk products (Garde et al., 2012). $\mathrm{pH}$ from the analysed samples ranged between 6.40 and 6.53, Alba samples having the most acidic $\mathrm{pH}$ (mean of 6.47), Hunedoara and Bihor milk samples with similar values (6.51-6.52). The general observation for Alba and Bihor Counties, was that $5^{\text {th }}$ lactations and up provided the highest fat, protein and lactose content in all farms located in these two regions. The explanation is that the higher the lactation, the lower the amount of milk is obtained, and the lower milk quantity, the higher fat and protein is determined. Aminecontaining compounds from milk (urea), ranged between $24.59 \mathrm{mg} / \mathrm{dl}$ and $28.59 \mathrm{mg} / \mathrm{dl}$. Generally, milk from early lactations have lower amounts of urea in analyzed milk samples, and the average of all lactations have lower values than the upper lactation periods.

No significant differences were observed between the investigated parameters from of all locations, excepting some small differences (not statistically significant), these differences being attributed to geographical landscape and position where the farms are located.

Beside the nutritional value as a food for humans, milk is a favorable environment for the growth of microorganisms. For this reason, milk microbiology is an important parameter, both for consumers and for processing. Different tests are available to determine the milk microbiological quality. Bacteria, coliform and somatic cell counts are frequently used. According to the Regulation of the European Parliament no. No 853/2004 of specific hygiene rules for food of animal origin, the microbiological criteria for raw milk are as follows: raw cow's milk must have a total germ content (TGC) at $30{ }^{\circ} \mathrm{C}$ less than or equal to $100,000 / \mathrm{ml}$ and the somatic cell count (SCC) is less than or equal to $400,000 / \mathrm{ml}$.

Milk samples from Hunedoara County meet these regulations (Figure 1), both for SCC and for TGC, for the lactation periods, although the values were at the upper limit or slightly above. Samples from Alba and Bihor Counties presented the widest range of values for SCC and TGC, strongly 


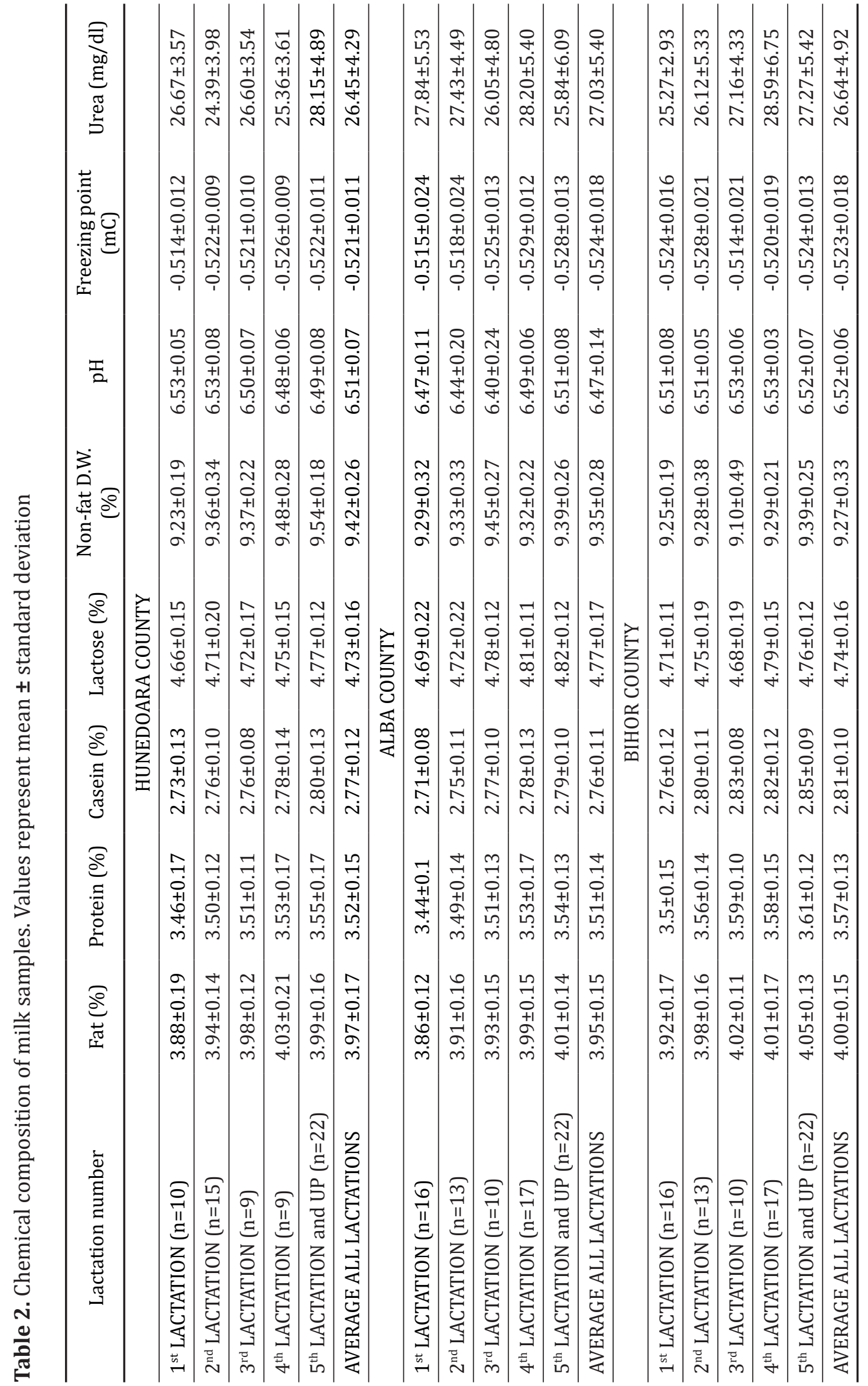




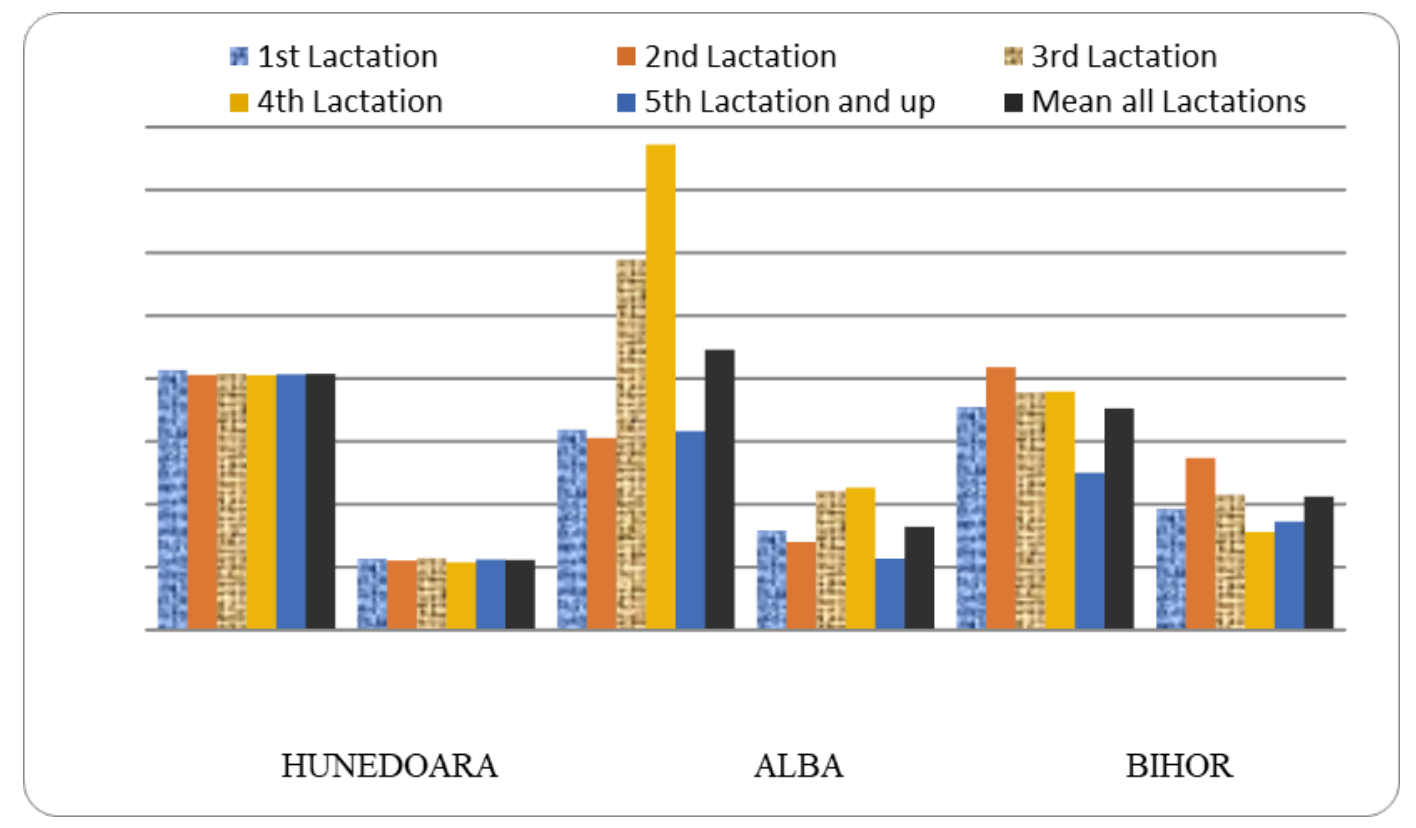

Figure 1. Comparative microbiologic quality of milk obtained from farms located in Apuseni Mountain area: Hunedoara, Alba and Bihor Counties

dependent on the lactation period. Thus, milk from Alba farms from $1^{\text {st }}$ lactation, $2^{\text {nd }}$ lactation and $5^{\text {th }}$ lactation had lower SCC values (305.36$318.51 \times 1000 / \mathrm{ml})$, but in $3^{\text {rd }}$ and $4^{\text {th }}$ lactation, the number of somatic cells were very much increased (589.05-772.40x1000/ml). Regarding TGC, all the samples collected from this county, exceeded the maximum values stipulated by the norms (113.69$226.62 \times 1000 / \mathrm{ml}$ ).

Samples from Bihor county, excepting the ones from $2^{\text {nd }}$ lactation $(417.96 \times 1000 / \mathrm{ml})$, meet the standards for total number of somatic cells (250.23-379.16x1000/ml), but TGC exceeded very much the maximum limit. For this reason, milk from this area, at the time of collection was not recommended for consumption.

Institute of Milk Quality (Iowa, USA) established four categories of milk quality using SCC determination:

- milk with low SCC $(<125,000$ cell/ml $)$ - high quality

- milk with medium SCC (125,000-249,000 cell/ $\mathrm{ml}$ ) - good quality

- milk with high SCC $(250,000-500,000$ cell/ml) medium quality

- milk with very high SCC $(>500,000$ cell.ml) unsuitable quality.
This is a more permissive classification, in Romania, the legislation establishes a maximum number of somatic cells of 400,000 cell $/ \mathrm{ml}$.

The farms where the study was conducted are considered organic farms, being situated in different mountain regions of Romania. Organic animal farming products gain more and more the attention of consumers, although they need more information regarding these products (Scozzafava et al., 2020). Amog the motivations of consuming orgsnic products are firstly heralth and second different environmental concerns (Rana \& Paul, 2017; Ceylan et al., 2018). Different studies show that Romanian organic products represent only a small percet of the total agro-food market (Roman, 2010; Vietoris et al., 2016; Ceylan et al., 2018). Studies over different farms located in the mountain regions, may lead to possible producer's identification, to increase the organic products market.

\section{Conclusion}

Both big and small bovine farms from the investigated regions, present in majority of cases, good quality milk, with physico-chemical parameters that were above the values reported abroad. The geographical origin of milk samples did not significantly influence the chemical parameters, but the microbiological quality was different in 
the three analysed bovine farms. Lactation number influences to a small extent the nutritional parameters of milk. Samples from Hunedoara County were the most uniform from microbiological point of view, all analysed samples (collected in all lactation periods), being within the Standard limits. More observations must be made in locations where high TGC and SCC were discovered, to exclude the possible presence of clinical or subclinical mastitis.

\section{References}

1. Alomirah $\mathrm{H}, \mathrm{Al}$-Mazeedi $\mathrm{H}, \mathrm{Al}$-Zenki $\mathrm{S}, \mathrm{Al}$-Aati T, Al-Otaibi J, Al-Batel M, Sidhu J (2007). Prevalence of antimicrobial residues in milk and dairy products in the state of Kuwait. Journal of Food Quality, 30: 745-763.

2. Banu C (2009) ed. Tratat de industrie alimentară. ASAB Publishing Bouse, Bucharest, Romania.

3. Bony J, Contamin V, Gousseff M, Metais J, Tillard E, Juanes X, Decruyenaere V, Coulon JB (2005). Factors of Variation of the Milk Composition on the Reunion Island. INRA Production Animales, 18: 255-263.

4. Bruhn JC, Frank AA (1997). Monthly variations in gross composition of California Herd Milks. Journal of Dairy Science, 60: 696-700.

5. Casati MR, Cappa V, Calamari L, Calegari F, Folli G (1998). Effects of the season on milk yield and on some milk characteristics in cows. Scienza e Tecnica LattieroCasearia, 49: 7-25.

6. Ceylan RF, Akpinar MG, Cherciov AM, Ozkan B, Gul M (2018). Consumer preferences of organic products for Romania. International Journal of Agriculture, Forestry and Life Science, 2(2): 47-55.

7. Codex Standard 206-1999, GENERAL STANDARD FOR THE USE OF DAIRY TERMS.

8. Council Directive 91/180/EEC: Commision Decision of 14 February 1991, Laying down certain methods of analysis and testing of raw milk and heat-treated milk. Official Journal Nr. L 93, pp 1-48.

9. Cziszter LT, Acatincăi S, Bognar A, Tripon I, Gavojdian D, Baul S, Erina S (2008). Study of morphological and milk production trains of a Romanian Black and white cow population from the south-western Romania. Bulletin UASVM Animal Science and Biotechnologies, 65(1-2): 156-160.

10. Demeyer D, Doreau M (1999). Targets and procedures for altering ruminant meat and milk lipids. Proceedings of the Nutrition Society, 58: 593-607.

11. El Mahdy C, Boaru A, Popescu S, Borda C, (2016). Water Quality, Essential Condition Sustaining the Health, Production and Reproduction in Cattle. A review. Bulletin UASVM Animal Science and Biotechnologies, 73(2): 113125.

12. Falchero L, Lombardi G, Gorlier A, Lonati M, Odoardi M, Cavallero A (2010). Variation in fatty acid composition of milk and cheese from cows grazed on two alpine pastures. Dairy Science and Technology, 90: 657-672.

13. Formaggioni P, Franceschi P, Summer A, Malacarne M, Fieni S, Mariani P (2002). Effects of the season and the herd on milk proteose peptone content and relationships with rennetcoagulation properties. Scienza e Tecnica Lattiero-Casearia, 53: 53-65.

14. Gîlcă I, Macovei V, Brebeanu D, Stănescu R, Ţicău E, Dubiţ $C$ (2008). Evaluation of the milk quality and udder health based on the somatic cell counts. Bulletin UASVM Animal Science and Biotechnologies, 65(1-2): 32-34.

15. Iurca IM, Răducu CM (2005). Tehnologia industrializării produselor animale, Academic Press Publishing House, Cluj-Napoca.

16. Karoui R, Martin B, Dufour E (2005). Potentiality of front-face fluorescence spectroscopy to determine the geographic origin of milks from the Haute-Loire department (France). Lait, 85: 223-236.

17. Kelsey JA, Corl BA, Collier RJ, Baumann DE (2003). The effect of breed, parity, and stage of lactation on conjugated linoleic acid in milk fat from dairy cows. Journal of Dairy Science, 86: 2588-2597.

18. Kilic A, Kilic S (1994). Feeding and Milk. Bilgehan Press, Izmir.

19. Matei ST, Groza I, Andrei S, Bogdan L, Ciupe S, Petrean A (2010). Serum Metabolic Parameters in Healthy and Subclinical Mastitis Cows. Bulletin UASVM, Veterinary Medicine, 67(1): 110-114.

20. Mehta BM (2015). Chemical Composition of Milk and Milk Products. In: Cheung P., Mehta B. (eds) Handbook of Food Chemistry. Springer, Berlin, Heidelberg.

21. Onaciu G, Jurco E, Negrea O (2015). The Study of ther Main Milk Production Traits of Red Holstein Breed, Raised in Sălaj County. Bulletin UASVM Animal Science and Biotechnologies, 72(2): 270-271.

22. Onaciu G, Jurco E, Ognean L (2016). Appreciation of the Mammary Gland Health Status Based on the Quality Traits of Milk Obtained from Friesian-Black Spottred Breed. Bulletin UASVM Animal Science and Biotechnologies 73(1): 1-6.

23. Othmane M, Carriedo JA, De La Fuente LF, San Primitivio F (2002). Factors affecting test day milk composition in dairy ewes and relationships amongst various milk components. Journal of Dairy Research, 69: 53-62.

24. Ozrenk E, Selcuk IS (2008). The effect of seasonal variation on the composition of cow milk in Van Province. Pakistan Journal of Nutrition, 7: 161-164.

25. Rana J, Paul J (2017). Consumer bedhavior and purchase intention for organic food: A review and research agenda. Journal of Retailing and Cosumer Services, 38: 157-165.

26. Răducu C, Mireşan V, Cadar M, Negrea O, Pusta D, Iurca I, Coroian A, Feștilă I, Cocan D, Constantinescu R (2012). Study on the Qualitty of Raw Milk Collected from Different Collecting Centers of Bistrița-Năsăud County. Bulletin UASVM Animal Science and Biotechnologies 69(1-2): 337-338. 
27. Răducu CM (2014). Prelucrarea și controlul calităţii produselor animale, AcademicPress Publishing House, Cluj-Napoca, Romania.

28. Răducu C, Mireşan V, Coroian A, Pop C, Coroian OC, Cocan D, Andronie L (2016). Study on the Milk Quality Parameters in Three Farms from Sălaj County. Bulletin UASVM Animal Science and Biotechnologies, 73(2), 256-258.

29. Roman GV (2010). Situaţia Agriculturii Ecologice în România, cited by Vietoris et al., 2016.

30. Sala CC (2008). Igiena, tehnologia şi controlul laptelui şi a produselor derivate, Eurobit Publishing House Timișoara, Romania.

31. Salovuo H, Ronkainen P, Heino A, Suokannas A, Ryhänen EL (2005). Introduction of automatic milking system in Finland: effect on milk quality. Agricultural and Food Science 14: 346-353.

32. Scozzafava G, Gerini F, Boncinelli F, Contini C, Marone E, Casini L (2020). Organic milk preference: is it a matter of information?. Appetite, 144: 104477.

33. SR EN ISO 1211: 2010 Lapte. Determinarea conținutului de grăsime. Metoda gravimetrică (Metodă de referinţă).

34. SR EN ISO 13366-3/2001 Somatic cell counting from milk. Part 3. Fluoro-opto-electric method.

35. SR ISO 6731: 1996. Lapte, smântână şi lapte concentrate. Determinarea conținutului de substanță uscată totală (Metodă de referinţă).

36. Sraïri MT, Benhouda H, Kuper M, LeGal PY (2008). Effect of cattle management practices on raw milk quality on farms operationg in a two-stage dairy chain. Tropical Animal
Health and Production, 41(2): 259-272. DOI: 10.1007/ s11250-008-9183-9.

37. Țibulcă $D$, Jimboreanu $M$, Sălăgean $C D$, Chelemen $R$, Țibulcă A, Crăciun M (2012). Monitoring the quality and hygiene of processed milk from Bistrița-Năsăud county. Journal of Agroalimentary Processes and Technologies, 18(1): c65-69.

38. Tucker HA (1989). Photoperiod affects intake, growth and milk production of cattle. Feedstuffs, 61: 15-16.

39. Usturoi MG (2007). Tehnologia laptelui şi a produselor derivate, Alfa Publishing House, Iaşi, Romania.

40. Van Nieuwenhove PC, Oliszewski R, González NS (2009). Fatty acid composition and conjugated linoleic acid content of cow and goat cheeses from northwest Argentina. Journal of Food Quality, 32: 303-314.

41. Viayakumar M, Park JH, Ki KS, Lim DH, Kim SB, Park SM, Jeong HY, Park BY, Lim TI (2017). The effect of lactation number, stage, length, and milking frequency on milk yield in Korean Holstein dairy cows using automatic milking system. Asian-Australas Journal of Animal Science, 30(8): 1093-1098.

42. Vietoris V, Kozelová D, Mellen M, Chreneková M, Potclan JE, Fikselová M, Kopkáš P, Horská E (2016). Analysis of consumer preferences at organic food purchase in Romania. Polish Journal of Food and Nutrition Science, 66(2): 139-146.

43. Yetismeyen A (2000). Milk Technology, Ankara University Agriculture Faculty, Ankara, Press No. 1511, Turkey. 